\title{
A Mobile-based Tea Farming Information System
}

\author{
Njeru Kenedy Munene \\ Faculty of Information Technology, \\ Strathmore University \\ Nairobi, Kenya
}

\author{
Bernard Shibwabo Kasamani \\ Lecturer, Faculty of Information Technology \\ Strathmore University \\ Nairobi, Kenya
}

\begin{abstract}
Current trends in information and communication technology have led to emergence of smartphones with faster wireless speeds, faster graphics, better screens, and faster processors. Tapping into this technology can lead to development of mobile information systems that promote sustainable farming through timely information access, especially in tea farming. The traditional practice in tea farming has been dissemination of information through extension officers, Farmer Field Schools, mass media or farmer's sharing own experience. Consequently, this vital information is either accessed too late or when obsolete and/or it is sometimes completely lacking. Limited access to information has led to an information gap hence farmers practice poor planning and farming resulting to environmental degradation and reduced revenues. This paper focused on developing a tea farming information system that meets the information needs of tea farmers. The nature of the study required the researcher to adopt deductive approach so as to compare the data findings against the existing literature through logical reasoning. A case study strategy was employed to gain a rich understanding of the research perspective with the focus being the tea farmers of Mungania Tea Factory Company Limited. Through qualitative and quantitative analysis, the research findings can be generalised to all the tea farmers. Agile system development methodology was employed due to its sustainable development having testing integrated throughout the lifecycle. The contribution of this research concerns adoption of a tea farming information system to improve on productivity, service delivery, profitability, decision-making and farmer protection from fraud and losses. Moreover, it facilitates the communication between the factory and the farmers giving easier access to extension services. It further enhances processing of more accurate and comprehensive information and generation of useful reports.
\end{abstract}

\section{Keywords}

Information access, Tea farming, Information system, Mungania, KTDA, USSD.

\section{INTRODUCTION}

ICTs have become more powerful, more accessible and more widespread contributing heavily to the increase in overall investment and efficiency of labour and capital [1, 2]. Agriculture has embraced agricultural biotechnology, machinery, and genetically produced plants and could benefit immensely by adopting ICTs. Mobile technologies which have evolved from analog communication in the First generation to digital communication in the Long-Term Evolution have brought simplicity and rich functionalities in communication.

A mobile information system should ensure that the user gets the relevant information based on the physical location, user preferences and time among other factors based on context awareness. The smartphones which have emerged are context- aware and adapt to highly dynamic environments, have embedded physical sensors, have data exchange capabilities and allow installation of applications to perform almost any task [3, 4]. These applications include SMS, USSD and other installable applications.

Challenges that keep many small hold farmers locked in poverty stem from a lack of access to market information, technical knowledge, inputs, financing and accessible markets where they can sell their products $[5,6]$. Current communication structures at Mungania Tea Factory Company Limited are through circulars and notices that are prone to mutilation. In some instances, information passage is through word of mouth from factory to the members in different green tea leaves collection centres.

Information-intensive enterprises including agricultural enterprises require provision of timely information. Mittal and Mehar [7] noted that information needs are growing rapidly with introduction of modern technologies, hybrid seeds and changing climatic changes hence farmers find traditional knowledge, experience and guesswork in decision making ineffective. The prohibitive high cost of face-to-face interaction and crumbling extension services underscores the need to lay emphasis on the potential of ICTs in disseminating agricultural information to targeted farmers $[7,8]$.

Use of circulars, notices and word of mouth in relaying information to the farmers has led to delayed delivery or complete total lack of access to information. Consequently, farmers practice poor planning and farming resulting to environmental degradation and reduced revenue for both farmers and the Government of Kenya. The paper therefore sought to address the problems faced by the farmers through developing an information system for timely provision of information on the go leading to faster and informed decisions.

This would provide for accurate and comprehensive information, generation of useful reports and search for specific information on the system as needed. To accomplish this, the researcher sought to answer four questions;

\footnotetext{
i. What is the information needs of tea farmers?

ii. What are the weaknesses to the existing information systems in tea farming?

iii. How will the proposed information system be designed and implemented to address the information needs of tea farmers?

iv. Does the proposed information system meet information needs of tea farmers to affect their decision-making?
}

The study was limited to tea growers who sell their produce at Mungania Tea factory. The factory is located on the SouthEastern Slopes of Mt. Kenya, Eastern Province, Embu County, Runyenjes Sub-County, Kagaari Location, 
Kianjokoma Sub location, Kiandong'o Village which is 20 kilometres from Embu County Headquarters and 152 kilometres from Nairobi, Kenya. The study was inspired by reduced yield for area under cultivation and environmental degradation which could be addressed by timely provision of quality agricultural information.

\section{LITERATURE REVIEW}

\subsection{Information Needs of Tea Farmers}

Ozowa [9] categorically grouped information needs into agricultural inputs, extension education, agricultural technology, marketing and agricultural credit. This is further supported by Odini [10] who indicated that farmers needed relevant and adequate information on agricultural inputs, marketing, selection of variety of seeds, high yield crops, pest control, fertiliser applications and problem-solving skills as demonstrated on Table 1. Agricultural inputs include the consumable and capital inputs required for organic farming for instance, seeds, fertilisers, agrochemicals, machineries and levelers.

Table Error! No text of specified style in document.. The kind of Information Needs

\begin{tabular}{|l|l|l|}
\hline Kind of Information & $\begin{array}{l}\text { Respondents } \\
\text { (F) }\end{array}$ & $\begin{array}{l}\text { Percentage } \\
(\mathbf{\%})\end{array}$ \\
\hline Agricultural inputs & 120 & 80 \\
\hline $\begin{array}{l}\text { Improved variety of } \\
\text { seeds }\end{array}$ & 103 & 67 \\
\hline Access to credit & 100 & 67 \\
\hline Marketing & 97 & 65 \\
\hline Weed control & 87 & 58 \\
\hline Cultivation techniques & 87 & 58 \\
\hline Harvesting techniques & 86 & 57 \\
\hline Animal husbandry & 80 & 53 \\
\hline Home economics & 78 & 52 \\
\hline Crop management & 72 & 48 \\
\hline Farm management & 72 & 48 \\
\hline Soil conservation & 66 & 44 \\
\hline Farm mechanisation & 64 & 42 \\
\hline Land ownership & 59 & 39 \\
\hline
\end{tabular}

The required Extension education refers to the practical skills on how various technologies or agricultural practices are to be carried out. Farmers further require information on technologies that make-work easier and boost production as well as access to those agricultural technologies. In addition, farmers need to be trained and informed on how they could have access to credit to boost their production or purchase needed technological inputs. Lastly, to market their produce, information about market prices helps eliminate middlemen as well as give the farmer a choice of where to sell products leading to higher returns. Having ready markets eliminates post-harvest losses.

\subsection{Existing Information Systems in Use}

Age, farm size, gender, literacy levels, land ownership, credit access and desire to produce more can be identified as some of the factors influencing information access and technology adoption. According to Katungi, Edmeades and Smale [11], older farmers seemed less likely to engage in information receiving and providing which could be due to their low ability to communicate. Hite, Hudson and Intarapapong [12] observed that farm size, farming experience and education influence the adoption of technologies. Male farmers are engaged in more geographically dispersed social networks, thus giving them a greater chance to access information [13]. Large families tend to seek more information due to the need for satisfying family consumption as well as higher number is exposed to get information.

Manda [14] noted that interventions by international NGOs, overdependence on foreign funding for research and development in agriculture and private sector involvement could further increase information gap between the haves and the have-nots. On the contrary, the researcher views these interventions as having immensely contributed to the development of agriculture therefore coordination of research, information sharing and dissemination is what ought to be addressed. Agricultural innovation is largely affected by information available on the innovation and how well that knowledge is passed to the stakeholders [15-18]. This calls for a reliable and efficient information system that is not subject to the enumerated limitations.

\subsubsection{Agricultural Dissemination Channels}

Effective information access requires dissemination channels to be oriented towards the user's needs, as well as the types and levels of information and in forms and language preferred by the user [19-20]. Information is delivered to farmers through monthly magazine, agricultural radio programmes, films and posters by extension agents, web portal, social media, newspapers, notice boards, use of leaflets, exhibits, public campaigns, banners, visual aids, text (SMS) based service, self-support online community, interactive video conferencing service and mobile Internet based service $[9,14$, 21-25].

These methods come with delays, lack convenience and may not be relevant to the specific needs of the farmer. The major contribution by extension officers has been promotion of good management practices with farmers using field days, demonstrations and direct advice but they have suffered from limited numbers and cultural inhibitions [21, 26]. Whereas mass media is effective in creating awareness of an innovation it might have limited influence on their adoption.

Mitei [26] further observed that a successful implementation of Farmer Field Schools resulted to better empowerment, access to information, personal development, conflict resolution, and relationship with the factory and leadership ability. A Web portal host a collection of relevant websites hence gives easy access to extensive information to the farmer. Voice based service disseminates information through phones and online voice calls giving an interactive and individualised service to farmers.

Text based services disseminate information through mobile phone texts bringing on board efficiency, effectiveness and timely information. Online community provides an interactive platform with membership of farmers and experts that derives its success on stakeholders' participation. Interactive video conferencing service also demands interactive communication since information dissemination is by online conferencing. Use of mobile phone technology to deliver agricultural information is on the increase as demonstrated on Table 2 from a research conducted by Gakuru, Winters and Stepman [27]. 
Table 2. Technology Used to deliver Agricultural Information

\begin{tabular}{|l|l|}
\hline Technology Used & Number of Projects \\
\hline Internet & 47 \\
\hline Radio & 17 \\
\hline Television & 2 \\
\hline CD-ROM/Video/DVD & 6 \\
\hline Mobile phone & 22 \\
\hline IVR & 4 \\
\hline SMS & 16 \\
\hline Telephone (Call - in) & 4 \\
\hline Dial - Up radio & 1 \\
\hline GIS & 1 \\
\hline
\end{tabular}

\subsubsection{Mobile Technologies in Agriculture}

Mobile technology has made communication and information access convenient and timely to users. Applications like FarmGraze [28], M-Shamba [29] and Horse Ration App [30] demonstrate some of services farmers' access through realtime communication. FarmGraze is an Android application that helps the farmer to measure, record and manage grazing by saving time, and unnecessary feeds and fertilizer. It mainly deals with dairy cows, beef cattle and sheep. HorseRATION helps the farmer to accurately calculate the amount of feed to give to the horse helping to save money and repercussions that would result from overfeeding.

M-Shamba is an Android application that further includes SMS and web platforms that enables farmers to access information on crop production as well as link them to the market. Dialog Tradenet [31] disseminates agricultural information through SMS, USSD and web. WeFarm [32] allows farmers to share information via SMS. A farmer can ask question on farming and receive a crowd-sourced answer from other farmers around the world in minutes. Virtual City [33] has helped KTDA to keep track of green tea leaves leading to an increased delivery yield per farmer. This is done through tracking quantities and qualities delivered to the collection centres.

M-PESA, which is a fast, secure and convenient way to transact on mobile, adoption for Factory Door Sales (FDS) has curbed loses related with cash transactions. It has further facilitated audit on money raised and utilised through FDS, increase accountability and transparency as well as save time on financial reconciliation since M-PESA is automated [34]. WeFarm suffers from the weaknesses of an SMS service and that the crowd sourced solutions might not be applicable in a given locality. Moreover, Virtual City only tracks the delivery of the farmer yield but does not meet information needs for farming. These needs are being addressed by this research.

\subsection{Weaknesses Identified in Existing Systems}

The following existing gaps were identified:

Limited access by extension officers: Few officers and cultural inhibitions for interaction with women farmers limit their interaction with farmers [21, 35]. Zulberti [36] further argues that extension officers have inadequate resources, insufficient communication capacity, limited knowledge and skills and they are affected by poor infrastructure and farmers lack of basic farm resources.

Lack of targeted information: Mass media like radio, television, film, video, magazines, leaflets, audiocassettes, newspapers, web portal, leaflets and posters may not address specific farmer needs since it is not tailored to the needs of rural populations [37]. There is also issue of poor reception, and coverage in some areas. Limited reach and technical language used may be restricting or incomprehensible to the farmer. In addition, agricultural shows have poor attendance by farmers and many are structured as avenues for showcasing rather than training.

High Cost: Khatam et al. [38] observed that Farmer Field Schools (FFS) suffered from being expensive to implement, time consuming and having a difficult weekly routine to attend school and requires extension officers or experts. Voice based services are more expensive, time consuming, less efficient, require human involvement and machine to produce voice, lack pictorial illustration and not readily embraced by farmers $[25,27]$.

Limited reach and capacity: Libraries are limited by their location in urban areas. Moreover, text based service are limited in information they carry to provide comprehensive and in-depth information to address specific needs, require basic level of literacy besides being relatively costly. Online communities and interactive video conferencing require interactive communication with experts making them time consuming, costly and less efficient.

Unreliability: Relying on social media for information access leads to identity misuse, privacy and security issues and invalid information dissemination causing misunderstanding [22].

\section{METHOD}

\subsection{Software Development Methodology}

This study sought to design, develop and test an information system to meet information needs of tea farmers. The researcher employed Agile system development methodology with Scrum as they would offer flexibility and adaptable rapid delivery of software product through iterative feedback loop and time-boxed sprints [39-42]. The cycle of activities undertaken under Scrum involved Planning, Analysis, Design, Implementation, Unit and Acceptance testing.

Planning phase incorporated stakeholders' identification, determining the population sample and preparing and executing documents reviews, questionnaires and interviews. Visual Studio Team Foundation Server was used to determine the tasks to be carried out. During Requirement Analysis phase the analysis, presentation and interpretation of the collected data using Microsoft Excel 2011 was done. This was useful in identifying the information needs of the farmers and existing system weaknesses as well as required system features. A conceptual model for the information system with the required features was formulated during the Design phase.

Architectural design, UML diagrams, Database and wireframes were also developed by use of creately.com and draw.io. The modules and components of the information system were developed during the Implementation phase. These phases were carried out iteratively to ensure that the final product met the user needs. The tools used included Android Studio, Sublime Text, Apache, Bootstrap and MySQL. Finally, the Unit and Acceptance Testing phase was conducted through functional testing, usability testing and 
compatibility acceptance testing and the results documented. Tools used included Android Emulator, Postman Client and a questionnaire to get the feedback from the users. A validation was undertaken to verify that the system managed to address the problem as envisioned. Survey questions were used to ascertain the level of satisfaction with the application from the users.

\subsection{Research Design}

The research sought to understand the information needs of tea farmers, existing information systems and their weaknesses as well as determine the applicability of a mobile information system in relaying information. Qualitative design was used in determining the information needs of the farmers as well as evaluating the existing system weaknesses and was conducted through interviews and document review. Document reviews were carried out under literature review.

The researcher also used quantitative design through the use of a questionnaire to carryout system testing. The analysis of the results of this questionnaire determined whether the developed system met the user requirements. Surveys were also issued to determine whether system managed to accomplish the purpose for which it was developed.

System Analysis involved identifying, modelling and documenting the data requirements, data movements in the system and the events that affect each entity during the sequence that the events occurred. The researcher applied document review and interviews to identify and document the requirements. The study was carried out in Embu County at Mungania Tea Factory Company Limited. The researcher chose this location as they are well versed with the terrain of the area providing a higher probability of getting cooperative respondents.

The factory currently has 9,024 farmers some of whom are also its employees. They offered information on technologies, inputs, credit and marketing. The researcher focused on a sample size of 43 farmers obtained by selecting a confidence level of $95 \%$ and a confidence interval of 15 as shown next [43].

$\mathrm{SS}=\frac{Z^{2} *(P) *(1-P)}{C^{2}}$

Where:

$\mathrm{Z}=\mathrm{Z}$ value

$\mathrm{P}=$ Percentage picking a choice, expressed as decimal

$\mathrm{C}=$ Confidence Interval expressed as decimal

$\mathrm{S}=\frac{1.96^{2} *(0.5) *(1-0.5)}{0.15^{2}}=42.68$

Approximated to 43 farmers.

Document review involved review books, journals, company's database and articles to collect secondary data.
The review purposed to identify existing system weaknesses as well as identify some of the information needs of tea farmers. Qualitative interviews were used to provide in-depth findings through discussions with the respondents on the information needs of tea farmers. The interviews were conducted on the 43 farmers and the findings helped in designing of the system.

\section{SYSTEM ANALYSIS AND DESIGN 4.1.Requirements Analysis}

Based on the results, the researcher deduced the information needs of tea farmers as agricultural inputs, marketing information, technology information, credit information and extension education. The farmers thus required a system that could help in information verification and availing adequate information on the go. This would handle the current challenges of lack of verification, delays in delivery, inadequate information, complexity of FFS, limited access to extension officers, information sources and literacy levels.

\subsection{System Architecture}

The general architecture of the system is a mobile and USSD client for collecting and receiving data and a web application and database server for processing and storage of data respectively as shown in Fig 1. Users download and install the application on any Android based phone and requires registration to access information.

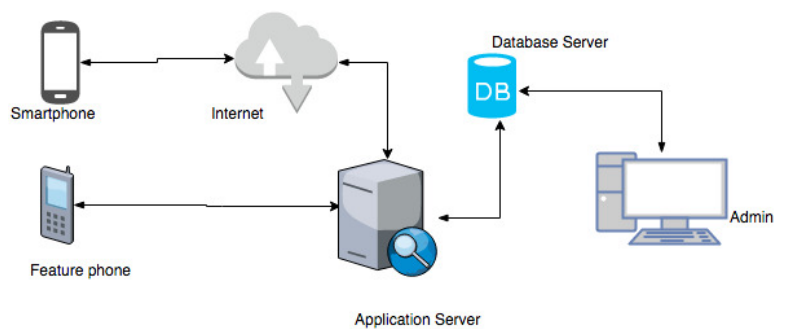

Fig 1: Tea farming Information System Architecture

The use case in Fig 2 demonstrates the information that a farmer can access. This includes information on fertilizer application, pest control, seedlings, credit and finance, pruning, auction details and firewood sale. Moreover, the farmer can book an event they would consider attending, they can report illegal practices by other farmers as well as reserve seedlings sale. In addition, they can search for specific information and view various reports. On the other hand, the administrator registers and approves the users of the system as well as creating and updating agricultural information on the system. 


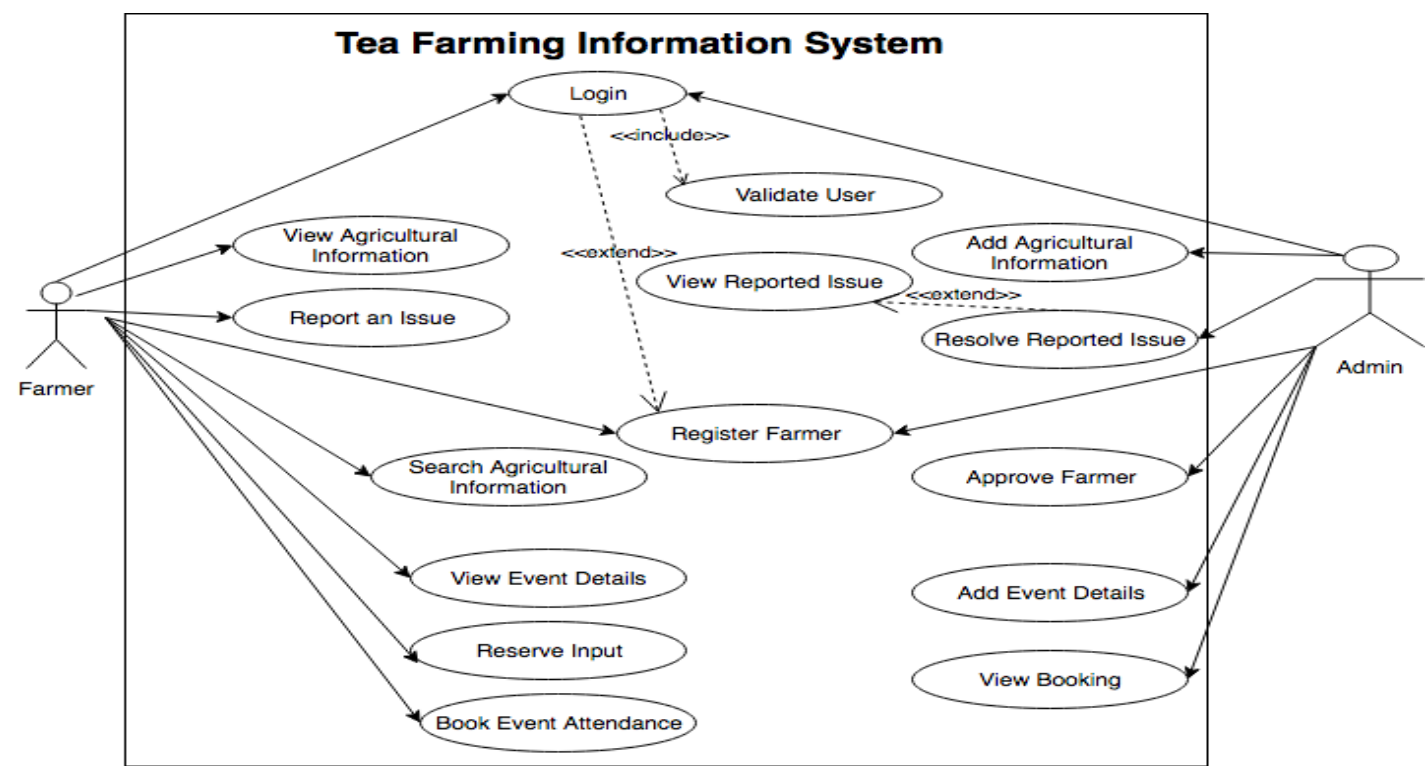

Fig 2: Use Case Diagram for the Tea Farming Information System

\subsection{Database Design}

Fig 3 shows the Entity Relationship diagram, the different application tables and their relationships. In the diagram there is the Farmers table, Feedback table, Collection Center table,
Report Incidence table, Bookings table, Events table, Seedling table and Reserve seedling table.

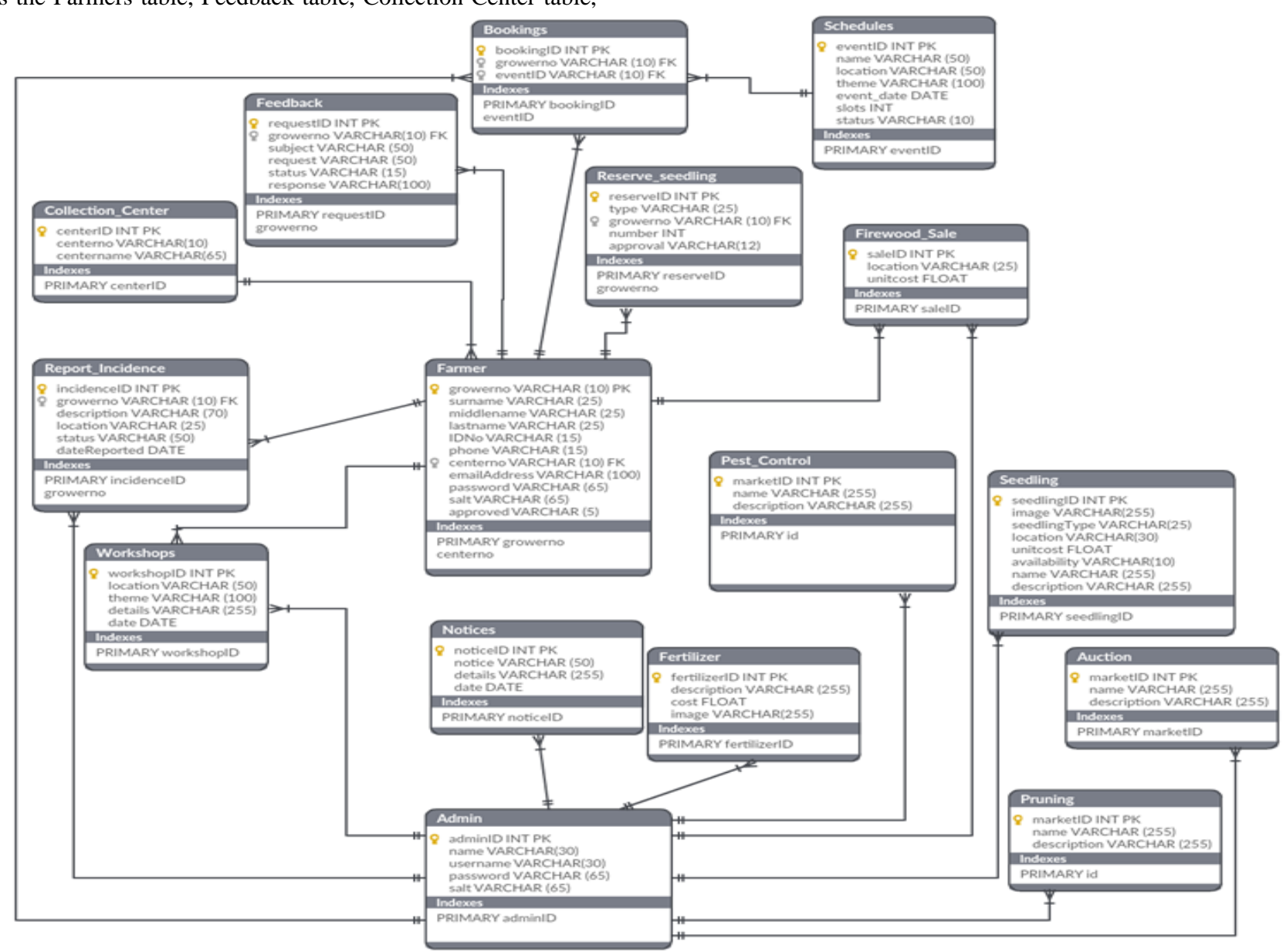

Fig 3: Entity Relationship Diagram for the Tea Farming Information System 


\section{SYSTEM IMPLEMENTATION AND TESTING \\ 5.1.System Development Tools}

The implementation of the tea farming information system involved developing of a native application, a USSD application and website for the backend administration. The native application was implemented on Android version 4.2 and above. The web technologies used were PHP, Bootstrap and JSON. The USSD module that provides data to users without a smart phone was built on PHP for server side scripting to enable the mobile application to communicate with the external database hosted on a server. MySQL was used as the database management system for the system.

\subsection{Application Frontend}

The following screenshots are excerpts from the modules demonstrating how the system was implemented. Fig 4 shows a menu for some of the services offered whereas Fig 5 demonstrates a booking undertaken by the user.

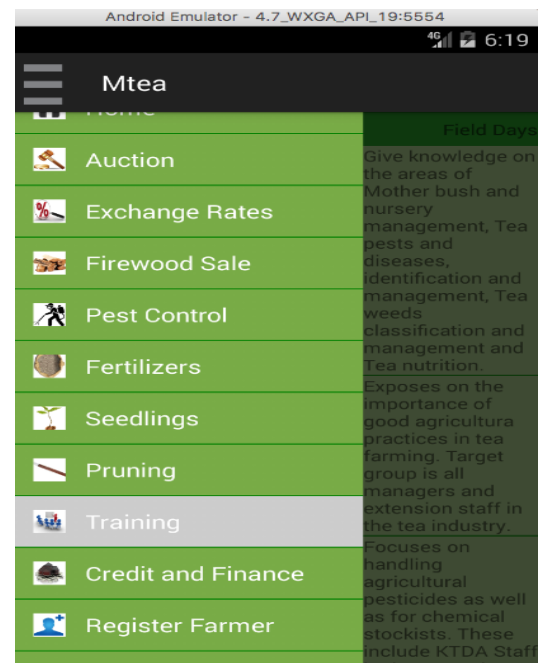

Fig 4: Screenshot of System Services

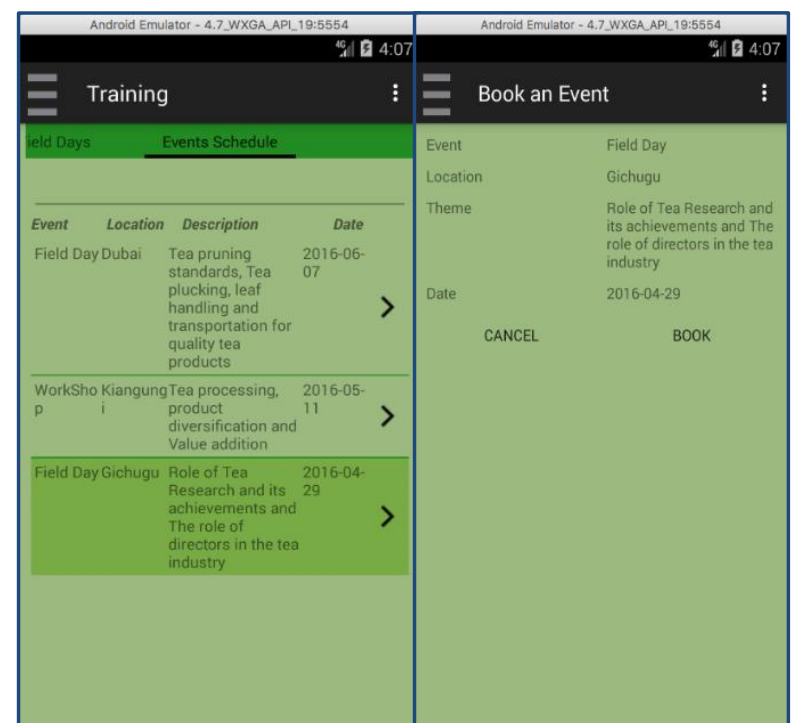

Fig 5: Screenshots showing Booking

\subsection{Application Backend}

Fig 6 shows the implementation of the backend for the system and the various actions that the administrator would perform.

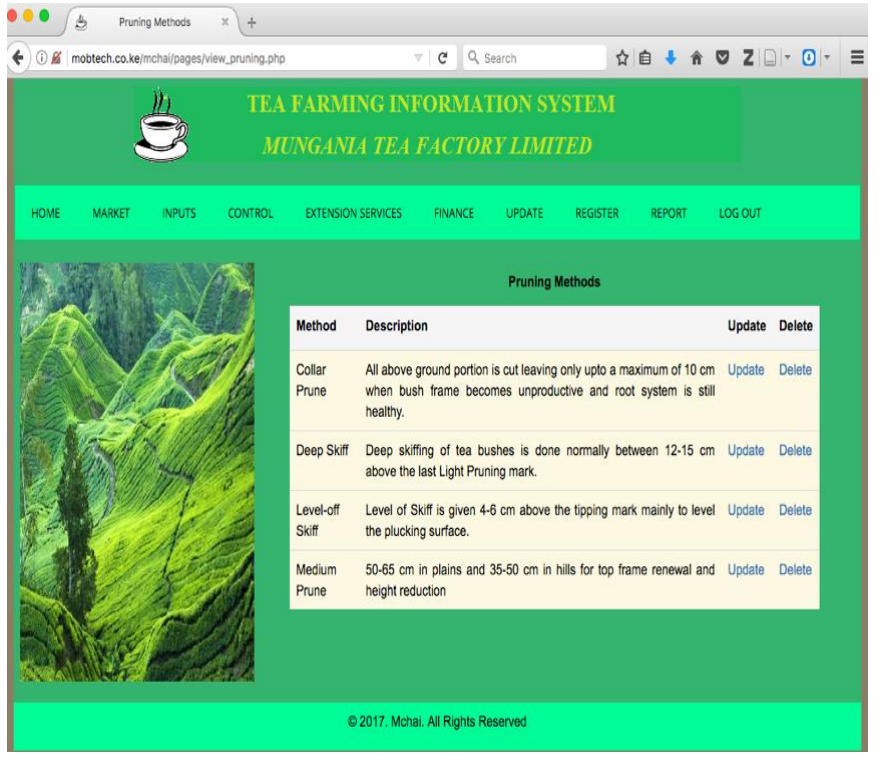

Fig 6: Screenshot of System Backend

\subsection{System Testing}

Functional testing, usability testing and compatibility testing were carried out on the system. Under functional testing, it was ascertained that the functionalities provided by the application were working as expected and all executed without errors hence ensuring stability of the system. Usability testing was carried out to verify the ease of use of the system, overall acceptance and how user friendly the system was. The system was rated to have an excellent ease of data entry and ease of navigation. It was also rated as having a good feedback and appearance. We further found out that the system works with various versions of Android and models of smartphones as indicated on Table 3 .

Table 3. Compatibility Testing Results

\begin{tabular}{|c|c|}
\hline Type of Smartphone & Compatible [Yes/No] \\
\hline $\begin{array}{c}\text { Tecno Phantom 6 - Android } \\
\text { Version 6.0 }\end{array}$ & Yes \\
\hline $\begin{array}{c}\text { Samsung Galaxy A5 (2016) - } \\
\text { Android Version 5.1.1 }\end{array}$ & Yes \\
\hline $\begin{array}{c}\text { Tecno C8 - Android Version } \\
5.0 .2\end{array}$ & Yes \\
\hline $\begin{array}{c}\text { HTC 820 Desire - Android } \\
\text { Version 4.4.2 }\end{array}$ & Yes \\
\hline $\begin{array}{c}\text { Tecno H6 - Android Version } \\
4.4 .2\end{array}$ & Yes \\
\hline
\end{tabular}

The researcher undertook system validation by determining and documenting system requirements, system testing, issuing a survey and providing an installation protocol. All the requirements specifications identified were included in the final system that was successfully tested to ascertain that the system solved the problem identified. Testing was conducted through questionnaire administered to thirty (30) respondents to help test the functionality, usability and compatibility of the system and the lessons learned documented section of this paper. The survey results gave the application an excellent overall rating in terms of meeting the information needs of tea farmers. The respondents further rated the relevance of information in the application as appropriate to influencing their decisions. Fig 7 shows the data entry rating test results. 


\section{Data Entry Rating}

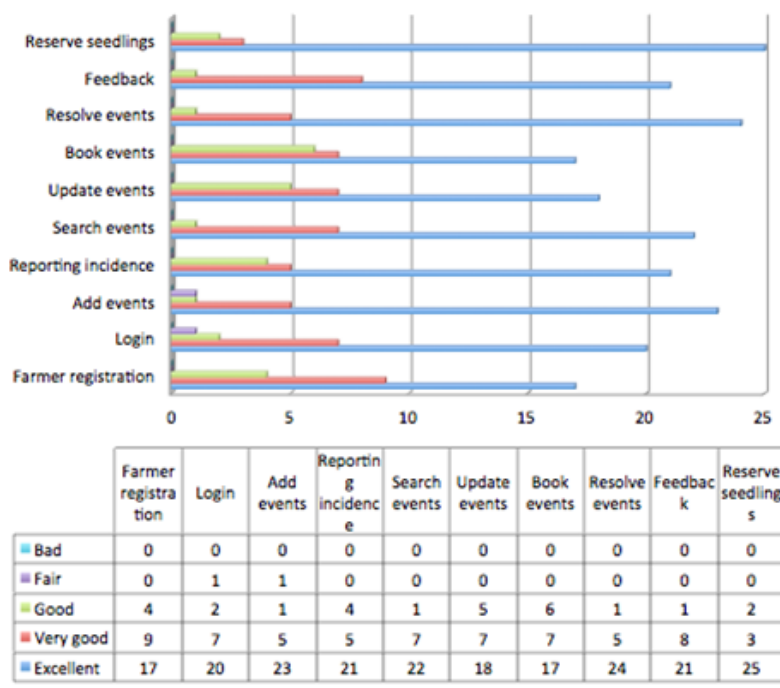

Fig 7: Data Entry Rating Test Results

\section{CONCLUSION}

The existing challenges that farmers face while seeking agricultural information include lack of awareness, low literacy level and uncoordinated research and dissemination of information. It was found that lack of information or inadequate information is a major contributor to information gap and lack of adoption to available technologies. Consequently, the smallholder farming systems are less productive and profitable, less value addition and increased cost of production. This study therefore addressed these issues by developing a mobile based tea information system. The system was put to test and validated and the respondents voiced their satisfaction that the functionalities worked out as expected to meet the intended purpose.

Further research, improvement and development ought to be conducted in this area to improve the overall user experience. Some of the areas to be considered include: Incorporating Global Positioning System for precision, Integration with existing systems especially at Mungania Tea Factory Company Limited, including other mobile platforms like Windows Phone and IOS as well as other languages for example Swahili so as reach more farmers. Additionally, on impact assessment, further study ought to be carried out to assess the significance brought about by the use of the tea farming information system.

\section{ACKNOWLEDGEMENTS}

Thank you Strathmore University for the support in this study, especially thanks to the Faculty of Information Technology.

\section{REFERENCES}

[1] Dutta, S., Geiger, T., and Lanvin, B. 2015. The global information technology report 2015. In World Economic Forum (Vol. 1, No. 1, pp. P80-85).

[2] Pilat, D., and Lee, F. C. (2001). Productivity Growth in ICT-producing and ICT-using Industries.

[3] Gu, T., Pung, H. K., and Zhang, D. Q. 2004. A middleware for building context-aware mobile services. In Vehicular Technology Conference, 2004. VTC 2004Spring. 2004 IEEE 59th (Vol. 5, pp. 2656-2660). IEEE.
[4] Zheng, M., Wei, B., Zhang, Z., and Yan, X. 2014. Adaptive Mobile Applications to Dynamic Context. Journal of Computer and Communications, 2(09), 9. http://dx.doi.org/10.4236/jcc.2014.29002.

[5] Okello, J. J., Okello, R. M., and Ofwona-Adera, E. 2009. Awareness and the use of mobile phones for market linkage by smallholder farmers in Kenya. E-agriculture and e-government for global policy development, 1-18.

[6] Winter, S. 2012. A growing lifeline: Mobile technologies in agricultural development. Retrieved August 23, 2016, from http://www.technoserve.org/blog/a-growinglifeline-mobile-technologies-in-agriculturaldevelopment.

[7] Mittal, S., and Mehar, M. 2012. How mobile phones contribute to growth of small farmers? Evidence from India. Quarterly Journal of International Agriculture, 51(3), 227.

[8] Fischer, R. A., Byerlee, D., and Edmeades, G. O. 2009 Can technology deliver on the yield challenge to 2050. In Expert Meeting on How to feed the World in (Vol. 2050, pp. 1-48).

[9] Ozowa, V. N. 1995. Information Needs of Small Scale Farmers in Africa: The Nigerian Experience. Consultative Group on International Agricultural Research (CGIAR) Newsletter, 4(3), 10-12.

[10] Odini, S. 2014. Access to and use of agricultural information by small scale women farmers in support of efforts to attain food security in Vihiga County, Kenya. Journal of Emerging Trends in Economics and Management Sciences, 5(2), 100.

[11] Katungi, E., Edmeades, S., and Smale, M. 2008. Gender, social capital and information exchange in rural Uganda. Journal of international development, 20(1), 35-52.

[12] Hite, D., Hudson, D., and Intarapapong, W. 2002. Willingness to pay for water quality improvements: The case of precision application technology. Journal of Agricultural and Resource Economics, 433-449.

[13] Haddad, L., and Maluccio, J. A. 2003. Trust, membership in groups, and household welfare: Evidence from KwaZulu-Natal, South Africa. Economic Development and Cultural Change, 51(3), 573-601.

[14] Manda, P. A. 2002. Information and agricultural development in Tanzania: a critique. Information Development, 18(3), 181-190.

[15] Arumapperuma, S. 2008. The role of information technology in disseminating innovations in agribusiness: a comparative study of Australia and Sri Lanka (Doctoral dissertation, Victoria University).

[16] Barrios, E. B., Ryan, J. G., and Daquis, J. C. P. 2011 Impact assessment of the e-AGRIKultura project: Philippines. Praise for this book, 89.

[17] Baumüller, H. 2012. Facilitating agricultural technology adoption among the poor: The role of service delivery through mobile phones.

[18] Ogutu, S. O., Okello, J. J., and Otieno, D. J. 2014 Impact of information and communication technologybased market information services on smallholder farm input use and productivity: The case of Kenya. World Development, 64, 311-321. 
[19] Barbara, G. and White, D. 2001. Developing an effective dissemination plan. United States of America. Retrieved September 27, 2016, from http://bir.ou.edu/files/bir/docs/Dissemination_plan.pdf.

[20] Monu, E. D. 1982. " Improving Agricultural Practices among African Smallholders"-The Contribution of Adoption and Diffusion of Innovation Research to Agricultural Development in Africa. African Studies Review, 25(4), 117-126.

[21] Asenso-Okyere, K., and Mekonnen, D. A. 2012. The importance of ICTs in the provision of information for improving agricultural productivity and rural incomes in Africa. African Human Development Report. UNDP Sponsored Research Series.

[22] Bertot, J. 2012. The impact of polices on government social media usage. Retrieved from Science Direct: http://www.sciencedirect.com/.

[23] Oxford University. 2003. Shortcomings of health information on the Internet. Oxford Journal.

[24] Vance, K. 2009. Social Internet Sites as a Source of Public Health Information. Retrieved from Science Direct: http://www.sciencedirect.com.

[25] Zhang, Y., Wang, L., and Duan, Y. 2016. Agricultural information dissemination using ICTs: A review and analysis of information dissemination models in China. Information Processing in Agriculture, 3(1), 17-29. http://dx.doi.org/10.1016/j.inpa.2015.11.002.

[26] Mitei, Z. 2011. Growing sustainable tea on Kenyan smallholder farms. International Journal of Agricultural Sustainability, 9(1), 59-66.

[27] Gakuru, M., Winters, K., and Stepman, F. 2009. Innovative farmer advisory services using ICT. documento presentado en el taller de W3C "Africa perspective on the role of movile technologies in fostering social development", Maputo, 1.

[28] Chase, J. "Farmgraze is a mobile application made by farming experts at Aberystwyth University, UK" Retrieved September 17, 2017, from http://www.mobilefarmapps.com/farm-graze.html.

[29] Vutagwa, C. "Meet Calvince Okello, founder of MShamba" Retrieved September 17, 2017, from http://techmoran.com/meet-calvince-okello-founder-ofm-shamba/\#sthash.2WOdEYrB.dpbs.

[30] Farrell, C. "HorseRATION is a mobile application made by Equine experts at Aberystwyth University, UK" Retrieved September 17, 2016, from http://www.mobilefarmapps.com/horse-app.html.
[31] Dialog. 2009. Dialog Tradenet - GGS Partnership Set to Revolutionise Agri Market Access. Retrieved from https://www.dialog.lk/news/dialog-tradenet-ggspartnership-set-to-revolutionise-agri-market-access/.

[32] Barthorpe, A. (2016). WeFarm: Data's role in sustainable tea production. Retrieved from http://wefarm.org/datasrole-in-sustainable-tea-production/.

[33] Thuo, H. 2016. GSMA: Creating impact for stallholder farmers through mobile technology in East Africa. Retrieved from https://www.gsma.com/mobilefordevelopment/tag/virtual -city.

[34] KTDA. KTDA MPESA Launch. Retrieved from http://www.ktdateas.com/index.php/blogs/item/18-ktdampesa-launch/18-ktda-mpesa-launch.html.

[35] Sibanda, L. M. 2012. Women farmers: Voiceless pillars of African agriculture.

[36] Zulberti, E. (n.d.). Agricultural Extension and Training Needs of Farmers in the Small Island Countries: A Case Study from Samoa. Retrieved from http://www.fao.org/docrep/008/y8345e/y8345e04.htm\#T opOfPage.

[37] Oakley, P., and Garforth, C. 1985. Guide to extension training (No. 11). Food and Agriculture Org.

[38] Khatam, A., Muhammad, S., Chaudhry, K. M., Mann, A. H., Haq, I., Khan, Z. U.,.. and Amin, H. (2010) Strengths and weaknesses of Farmers' Field Schools approach as perceived by farmers. Sarhad J. Agric, 26(26), 685-688

[39] Abrahamsson, P., Salo, O., Ronkainen, J., \& Warsta, J. 2002. Agile software development methods: Review and analysis.

[40] Highsmith, J. 2001. History: The agile manifesto. Sitio: http://www. agilemanifesto. org/history. html.

[41] Takeuchi, H. and Nonaka, I. (1986). The New Product Development Game. Harvard Business Review January Issue. Retrieved March 20, 2017, from https://hbr.org/1986/01/the-new-new-productdevelopment-game.

[42] Schwaber, K. 1997. Scrum development process. In Business Object Design and Implementation (pp. 117134). Springer London.

[43] Naing, L., Winn, T., and Rusli, B. N. 2006. Practical issues in calculating the sample size for prevalence studies. Archives of orofacial Sciences, 1(1), 9-14. 